\title{
Sustainable Public Spending Through Blockchain
}

\author{
By Judit Glavanits ${ }^{1}$
}

\begin{abstract}
$^{2}$
Blockchain technology and its industrial use cases can be detected worldwide. It is time for the state to think about the blockchain as an opportunity to reduce costs and build trust in the public spending. The paper and the presentation give an overview on how the state can apply the distributed ledger technology (DLT) and blockchain technology in the public administration: there are several countries with best practices already, and even more are in the introduction phase of opening to Industry 4.0 in the public services as well.

On the field of FinTech area the state has great responsibility to regulate (or at least define) the phenomena of cryptocurrencies, that is already in use for more than 10 years now without any responsible governmental acts. Within this topic the Central Bank Digital Currency projects are also discussed in the paper, which are supported by IMF, and declared as the next natural step forward on financial markets.
\end{abstract}

Keywords: blockechain, DLT, SDG, public spending

\section{Semantics: Blockchain and DLT (distributed ledger technology)}

The blockchain is defined by the World Bank in 2017 as " a particular type of data structure used in some distributed ledgers which stores and transmits data in packages called "blocks" that are connected to each other in a digital 'chain'. Blockechains employ cryptographic and algorithmic methods to record and synchronize data across a network in an immutable manner." This neutral definition contains the basic features of the technology, and the DLT is defined also in this manner as "novel and fast-evolving approach to recording and sharing data across multiple data stores (or ledgers). This technology allows for transactions and data to be recorded, shared, and synchronized across a distributed network of different network participants." (World Bank 2017).

The Bank of International Settlements defined DLT as "the processes and related technologies that enable nodes in a network (or arrangement) to securely propose, validate and record state changes (or updates) to a synchronized ledger that is distributed across the network's nodes" (BIS 2017)

The European Union has published several materia on blockchain technology and cryptocurrencies. The Policy Department for Economic, Scientific and Quality of Life Policies has published a study in July 2018 entitled "Cryptocurrencies and blockchain. Legal context and implications for financial crime, money laundering and tax evasion" (Houben end Snyers 2018) This title emphasizes the basic instincts on cryptocurrencies throughout Europe: this is the creation of the devil aiming to commit crime in the first place. However, blockchain technology is welcomed and supported in the EU. The European Union Blockchain Observatory and Forum (supported by the European

${ }^{1}$ Dr. jur. Judit GLAVANITS, PhD., associate professor, Széchenyi István University Faculty of Law and Political Sciences, Department of Public International and European Law. Co-founder of SmartLaw

${ }^{2}$ Acknowledgment - The research was supported by the European Union in the framework of the project GINOP-2.3.4-15-2016-00003. 
Commission) for example aims to accelerate blockchain innovation and the development of the blockchain ecosystem within the EU, and so help cement Europe's position as a global leader in this transformative new technology.

The Italian government has defined "blockchain" as "the technologies and computer protocols that use a shared, distributed, replicable register, accessible simultaneously, architecturally decentralized on cryptographic basis, such as to allow registration, validation, updating and archiving of data both in clear and further protected by cryptography, verifiable by each participant, not alterable and not modifiable" (Casalini 2019). Italy was among the first states regulated and defined the technology, while many countries still in the position of analyzing and understanding or even waiting for others for a good practice.

In the USA Congressman Paul Gosar introduced a bill to the House called "Cryptocurrency Act of 2020"1, which can be the regulation half of the world is waiting for. The proposed bill defines crypto-commodity, crypto-currency and crypto-security, together as digital asset. The bill defines decentralized cryptographic ledger - not DLT or blockchain. The aim of the bill, according to its text, is to "clarify which federal agencies regulate digital assets, to require those agencies to notify the public of any federal licenses, certifications, or registrations required to create or trade in such assets, and for other purposes."

Blockchains offer transnational and multilateral ways of co-working, with a possible inclusion of the machine-to-machine operations, partially or fully autonomous systems underpinned by tokens driven by self-executing code, perpetual scripts (like smart contracts), even with the possibilities of combining with Internet of Things (IoT) and artificial intelligence (Herian 2018). This way it is an engine for innovation in business, and also can be a helpful tool for governmental activities.

\section{SDG and Blockchain Technology}

The Sustainable Development Goals set in 2015 created a framework for a better world until 2030. The UN Intergovernmental Committee of Experts made a report on Sustainable Development Financing in August 2014 with a holistic view of financing SDGs. According to the Committee, the financing includes addressing:

(a) basic needs related to eradicating poverty and hunger, improving health and education, providing access to affordable energy and promoting gender equality;

(b) national sustainable development investment financing needs, such as for infrastructure, rural development, adaptation and climate resilient development, and energy; and

(c) global public goods, including the protection of the global environment and combatting climate change and its impact, as well as other areas (Report 2014).

1 Available here:

https://s3.cointelegraph.com/storage/uploads/view/a7b9c3d6c50453c5580820ef0b09f5e2.pdf (25th March 2020) 
For enabling the SDG sufficient efforts should be made on the field of financing governmental actions. Many of these actions can be solved or at least technically supported by DLT or blockchain. In the following table I would like to make some suggestions and show some international examples on best practices. We can observe that Europe and the United States leads (or at least aims to lead) the world in blockchain adoption and innovation, the usual dominance of the developed countries is now being challenged by Asia - and China in particular. China is specifically increasing its share of global blockchain financing with a focus on venture capital financing.. Blockchain-based applications and services are also spreading across some parts of Africa and Latin America (IFS, 2019).

The currently available literature on Sustainable Development Goals and blockchain or DLT technologies are basically focusing on the overall possible advantages of the innovative technologies (see: Adams at al 2018, Kewell et al 2017), or showing great examples on different achievement of each goals (see Tripoli and Schmidhuber 2018). In the following section I would like to give an overview of the SDG and blockchain technology by highlighting some good examples of the world economy.

\begin{tabular}{|c|c|c|}
\hline SDG & $\begin{array}{l}\text { How DLT/ blockchain } \\
\text { may help }\end{array}$ & International examples \\
\hline $\begin{array}{l}\text { Goal } 1 . \text { End poverty in all } \\
\text { its forms everywhere }\end{array}$ & $\begin{array}{l}\text { Digital currencies } \\
\text { cryptocurrencies, and } \\
\text { funding options make banking } \\
\text { and overall financial services } \\
\text { available on those territories } \\
\text { with lack of suitable } \\
\text { infrastructure }\end{array}$ & $\begin{array}{l}\text { Tajikistan: A pilot project } \\
\text { between UNDP's AltFinLab } \\
\text { and BitSpark company has } \\
\text { aimed to help migrant workers } \\
\text { in international money (asset) } \\
\text { transactions through } \\
\text { blockchain. Tajikistan is } \\
\text { underbanked and the } \\
\text { households depend on asset } \\
\text { transfers from family } \\
\text { members working abroad in a } \\
\text { large percent (about } 1 \text { million } \\
\text { people) (Petrovic et al 2017) }\end{array}$ \\
\hline $\begin{array}{l}\text { Goal } 2 \text {. End hunger, achieve } \\
\text { food security and improved } \\
\text { nutrition and promote } \\
\text { sustainable agriculture }\end{array}$ & $\begin{array}{l}\text { Food security can be } \\
\text { supported by blockchain and } \\
\text { smart contracts (traceability of } \\
\text { food), and make the } \\
\text { agricultural process more } \\
\text { transparent }\end{array}$ & $\begin{array}{l}\text { Ecuador: UNDP AltFinLab } \\
\text { in cooperation with } \\
\text { Amsterdam's FairChain } \\
\text { Foundation developed one of } \\
\text { the world's first blockchain- } \\
\text { based, shared-value } \\
\text { cholcolate. The blockchain } \\
\text { stores the information of the } \\
\text { cocoa's journey from } \\
\text { Amazonian farmers (who has } \\
\text { most of the benefit of this } \\
\text { new system) to UK retail } \\
\text { outlets - as customers. The } \\
\text { blockchain is monitoring } \\
\text { hygiene data in facilities and } \\
\text { time stamping them with }\end{array}$ \\
\hline
\end{tabular}




\begin{tabular}{|c|c|c|}
\hline & & $\begin{array}{l}\text { pictures and videos, also } \\
\text { tracking the food across the } \\
\text { entire supply chain via QR } \\
\text { code and Radio Frequency } \\
\text { Identification. With this } \\
\text { methodology blockchain } \\
\text { provides transparency and } \\
\text { authenticity to each product - } \\
\text { from farmers to the } \\
\text { consumers. }\end{array}$ \\
\hline $\begin{array}{l}\text { Goal 3. Ensure healthy lives } \\
\text { and promote well-being for } \\
\text { all at all ages }\end{array}$ & $\begin{array}{l}\text { Secure health data keeping can } \\
\text { make the service more } \\
\text { effective }\end{array}$ & $\begin{array}{l}\text { Several platforms are already } \\
\text { available, like MedRec (MIT) } \\
\text { or BlocHIE (Hong Kong) }\end{array}$ \\
\hline $\begin{array}{l}\text { Goal 4. Ensure inclusive } \\
\text { and equitable } \\
\text { quality } \\
\text { education and promote } \\
\text { lifelong } \\
\text { opportunities for all }\end{array}$ & $\begin{array}{l}\text { Secure keeping of graduation } \\
\text { data }\end{array}$ & $\begin{array}{l}\text { Malta: we should note that } \\
\text { Malta was one of the first } \\
\text { countries regulating } \\
\text { blochchain technology (and } \\
\text { cryptocurrency), so not } \\
\text { surprisingly it leads in applyint } \\
\text { the technology itself. Their } \\
\text { prototype blockchain store } \\
\text { and has the possibility to share } \\
\text { academic documents - as well } \\
\text { as prove that the credentials } \\
\text { belong to them. The system is } \\
\text { using the system of Blockcerts } \\
\text { open standard, which was } \\
\text { developed by MIT Media Lab } \\
\text { in } 2016 \text {. } \\
\text { USIZO project, South } \\
\text { Africa: Schools in need of } \\
\text { necessary funding (even for } \\
\text { electricity or water, school } \\
\text { supplies) have so called } \\
\text { Bankymoon meters installed, } \\
\text { which are blockchain based. } \\
\text { With this instrument anybody } \\
\text { from any country can make } \\
\text { payments directly to the meter } \\
\text { in many kind of crypto- } \\
\text { currency and fund the energy } \\
\text { or water, or any other needs } \\
\text { of the preferred school. The } \\
\text { driving force of this method } \\
\text { was to eliminate the costly and } \\
\text { sometimes unreliable } \\
\text { intermediaries from the } \\
\text { process of donation. }\end{array}$ \\
\hline Goal 5. Achieve gender & Anonimity of the DLT and & Afghanistan, Code \\
\hline
\end{tabular}




\begin{tabular}{|c|c|c|}
\hline $\begin{array}{l}\text { equality and empower all } \\
\text { women and girls }\end{array}$ & $\begin{array}{l}\text { blockchain can minimize } \\
\text { disadvantages of gender or any } \\
\text { kind of disabilities. According } \\
\text { to financial statistics from } \\
2018 \text { men represent } 65 \% \text { of } \\
\text { customers, they handle } 80 \% \\
\text { of loan volume and } 75 \% \text { of } \\
\text { deposits. (CARI 2018) }\end{array}$ & $\begin{array}{l}\text { Inspire project: In IT sector } \\
\text { there are much more man } \\
\text { employed, than women - this } \\
\text { is a worldwide fact. Women } \\
\text { Code to Inspire (CTI) aims to } \\
\text { provide a unique opportunity } \\
\text { for young women in } \\
\text { Afganistan to study coding } \\
\text { and programming. More than } \\
150 \text { young women has already } \\
\text { learned the basics of coding, } \\
\text { building mobile applications } \\
\text { and games. Over } 70 \% \text { of the } \\
\text { graduated students found } \\
\text { well-payed jobs. }\end{array}$ \\
\hline $\begin{array}{l}\text { Goal } 6 . \text { Ensure availability } \\
\text { and sustainable management } \\
\text { of water and sanitation for } \\
\text { all }\end{array}$ & $\begin{array}{l}\text { Public services can use smart } \\
\text { contracting, and with the } \\
\text { combination of IoT the } \\
\text { transparency greater }\end{array}$ & $\begin{array}{l}\text { California, IBM: IBM has } \\
\text { piloted blockchain and IoT } \\
\text { technologies for the } \\
\text { monitoring and oversight of } \\
\text { groundwater usage in } \\
\text { California's Sacramento - San } \\
\text { Joaquin River Delta, which } \\
\text { hydrologists consider to be } \\
\text { the nexus of California's } \\
\text { statewide water system and is } \\
\text { one of the largest and at risk } \\
\text { aquifers in North America. } \\
\text { The aim of the project's } \\
\text { scientists and engineers is to } \\
\text { lay a demonstration of how } \\
\text { the blockchain and internet- } \\
\text { of-things (IoT) sensors can } \\
\text { accurately measure } \\
\text { groundwater usage in manner } \\
\text { that is immediate (real-time) } \\
\text { and transparent. (see in detail: } \\
\text { Chohan 2019) }\end{array}$ \\
\hline $\begin{array}{l}\text { Goal } 7 \text {. Ensure access to } \\
\text { affordable, } \\
\text { sustainable and moder } \\
\text { energy for all }\end{array}$ & $\begin{array}{l}\text { Energy market is already } \\
\text { among the first users of the } \\
\text { new technologies with smart } \\
\text { contacts }\end{array}$ & $\begin{array}{l}\text { Share\&Charge (first in the } \\
\text { UK than Europe) } \\
\text { Share\&Charge began with the } \\
\text { simple idea of bringing the } \\
\text { advantages of blockchain } \\
\text { technology to Electric Vehicle } \\
\text { Charging. Since } 2017 \text {, together } \\
\text { with partners from all over the } \\
\text { world, they are developing } \\
\text { open source tools for a better } \\
\text { EV charging experience. }\end{array}$ \\
\hline Goal 8. Promote sustained, & blockchain & Blockchain system can make \\
\hline
\end{tabular}




\begin{tabular}{|c|c|c|}
\hline $\begin{array}{l}\text { inclusive and sustainable } \\
\text { economic growth, full and } \\
\text { productive employment and } \\
\text { decent work for all }\end{array}$ & $\begin{array}{l}\text { ecosystem can create new } \\
\text { jobs, and smart contracting is } \\
\text { available for labor } \\
\text { relationships. With the proper } \\
\text { administration }\end{array}$ & $\begin{array}{lrr}\text { temporary } & \text { work } & \text { more } \\
\text { transparent, and with smart } \\
\text { contracts the financial } \\
\text { transactions } & \text { can } & \text { be } \\
\text { decentralized } & \text { and better } \\
\text { administered. (see in details: } \\
\text { Pinna and Ibba 2019) }\end{array}$ \\
\hline 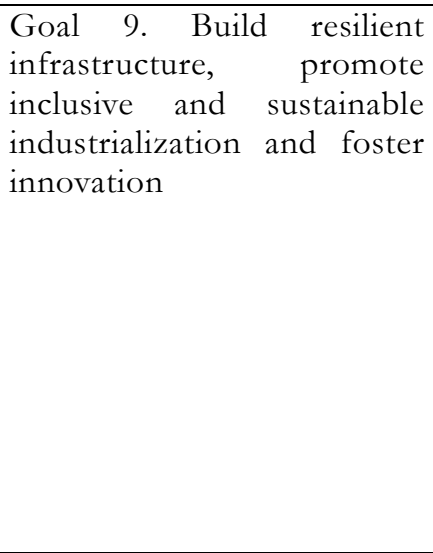 & $\begin{array}{l}\text { Property is one main focus of } \\
\text { DLT and blockchain: reform } \\
\text { of land registers, and multiple } \\
\text { ownerships are easier and } \\
\text { safer on blockchain. } \\
\text { According to the WEF, } 10 \% \\
\text { of the global gross domestic } \\
\text { product (GDP) will be stored } \\
\text { on blockchain by } 2027 \\
\text { (Kshetri 2017) }\end{array}$ & $\begin{array}{l}\text { Sweden: The Swedish Land } \\
\text { Registry, in cooperation with } \\
\text { ChromaWay, Kairos Future } \\
\text { and Telia Company } \\
\text { introduced pilot programs of } \\
\text { smart contracts and } \\
\text { blockchain for the process of } \\
\text { selling an immobile. This } \\
\text { solution can eliminate or } \\
\text { minimize the opportunity of } \\
\text { fraud and human errors, also } \\
\text { greatly reduce the } \\
\text { administrative costs and time } \\
\text { of land registration. }\end{array}$ \\
\hline $\begin{array}{l}\text { Goal } 10 . \text { Reduce inequality } \\
\text { within and among countries }\end{array}$ & $\begin{array}{l}\text { DLT and blockchain is } 100 \% \\
\text { transnational phenomena, } \\
\text { without any official } \\
\text { governmental control - so far }\end{array}$ & $\begin{array}{l}\text { Bitcoin: the commonly } \\
\text { known cryptocurrency's main } \\
\text { reason for existance was the } \\
\text { disappointment in the } \\
\text { traditional banking system. } \\
\text { Bitcoin and other } \\
\text { cryptocurrencies - by } \\
\text { bypassing the incumbent } \\
\text { institutions with their internal } \\
\text { politics - might offer } \\
\text { informal solutions that } \\
\text { operate beyond the formal } \\
\text { channels used by incumbents. } \\
\text { (see more: Scott 2016) }\end{array}$ \\
\hline $\begin{array}{l}\text { Goal 11. Make cities and } \\
\text { human settlements inclusive, } \\
\text { safe, resilient and } \\
\text { sustainable }\end{array}$ & $\begin{array}{l}\text { Reform of taxation systems } \\
\text { and smart city project can } \\
\text { make cities sustainable and } \\
\text { inhabitant-friendly. }\end{array}$ & $\begin{array}{l}\text { India: The smart city mission } \\
\text { of the Government of India is } \\
\text { transforming selected cities to } \\
\text { face the challenges of } \\
\text { urbanization. Bhopal is one } \\
\text { example for successful smart } \\
\text { city models, while Madhya } \\
\text { Prades won the award of } \\
\text { "Smart State of the Year" in } \\
\text { 2019, proving that the Indian } \\
\text { initiative is successful. } \\
\text { We should note that the } \\
\text { leading role model in building } \\
\text { smart cities with blockchain is }\end{array}$ \\
\hline
\end{tabular}




\begin{tabular}{|c|c|c|}
\hline & & $\begin{array}{l}\text { Dubai, which is also an award- } \\
\text { winner project, and also the } \\
\text { firs smart city built } \\
\text { blockchain-based. }\end{array}$ \\
\hline $\begin{array}{l}\text { Goal } 12 . \text { Ensure sustainable } \\
\text { consumption and } \\
\text { production patterns }\end{array}$ & \multirow{4}{*}{$\begin{array}{l}\text { SDG } 15 \text { is fundamental and } \\
\text { connects to most of the other } \\
\text { SDGs, in particular SDG 2, 3, } \\
6,12,13 \text { and } 14 \text {, because it } \\
\text { represents the very fabric of } \\
\text { most life on the planet. } \\
\text { Precision farming with the } \\
\text { help of the technology can } \\
\text { optimize the use of water and } \\
\text { pesticides. Global food } \\
\text { systems could rely on } \\
\text { blockchain, smart robots, and } \\
\text { the internet of things to } \\
\text { manufacture synthetic foods } \\
\text { for personalized nutrition. }\end{array}$} & \multirow{4}{*}{$\begin{array}{l}\text { FAO: Monitoring of the } \\
\text { implementation and } \\
\text { functioning of international } \\
\text { agreements are resourceful. } \\
\text { The distributed ledger } \\
\text { technology (DLT) and } \\
\text { blockchain innovations are } \\
\text { highly recommended by FAO } \\
\text { in hope that it can increase } \\
\text { transparency in food and raw } \\
\text { material supply chain, } \\
\text { efficiency in data storage and } \\
\text { traceability that leads to food } \\
\text { safety. (FAO 2019) }\end{array}$} \\
\hline $\begin{array}{l}\text { Goal 13. } \\
\text { urgent action to combat } \\
\text { climate change and its } \\
\text { impacts }\end{array}$ & & \\
\hline $\begin{array}{l}\text { Goal } 14 . \text { Conserve and } \\
\text { sustainably use the oceans, } \\
\text { seas and marine resources } \\
\text { for sustainable development }\end{array}$ & & \\
\hline $\begin{array}{l}\text { Goal 15. Protect, restore } \\
\text { and promote sustainable use } \\
\text { of terrestrial ecosystems, } \\
\text { sustainably manage forests, } \\
\text { combat desertification, and } \\
\text { halt and reverse land } \\
\text { degradation and halt } \\
\text { biodiversity loss }\end{array}$ & & \\
\hline $\begin{array}{l}\text { Goal 16. Promote peaceful } \\
\text { and inclusive societies for } \\
\text { sustainable development, } \\
\text { provide access to justice for } \\
\text { all and build effective, } \\
\text { accountable and inclusive } \\
\text { institutions at all levels }\end{array}$ & $\begin{array}{l}\text { The field of law enforcement } \\
\text { is supported by e- } \\
\text { identification, what leads } \\
\text { towards }\end{array}$ & $\begin{array}{l}\text { Procivis, Estonia and } \\
\text { Switzerland: Procivis is } \\
\text { developing a blockchain- } \\
\text { powered platform designed to } \\
\text { run a government-backed and } \\
\text { maintained "app store" } \\
\text { offering a complete list of } \\
\text { public services in } \\
\text { administration including } \\
\text { taxing, land register and } \\
\text { commercial registry. Estonia is } \\
\text { a leader in the EU on } \\
\text { blockchain-based technologies } \\
\text { and digital solutions. }\end{array}$ \\
\hline $\begin{array}{l}\text { Goal } 17 . \text { Strengthen the } \\
\text { means of implementation } \\
\text { and revitalize the Global } \\
\text { Partnership for Sustainable } \\
\text { Development }\end{array}$ & $\begin{array}{l}\text { The world economy has come } \\
\text { to the point of necessary } \\
\text { regulation of phenomena like } \\
\text { cryptocurrencies, DLTs and } \\
\text { blockchain-related } \\
\text { technologies and assests. The } \\
\text { harmonized regulatory } \\
\text { framework can be a first step } \\
\text { for maximizing the advantages } \\
\text { of these disruptive } \\
\text { technologies. }\end{array}$ & $\begin{array}{l}\text { EU: the European } \\
\text { Blockchain Observatory } \\
\text { and Forum is a good example } \\
\text { of international cooperation } \\
\text { on the field of getting the } \\
\text { most out of the blockchain } \\
\text { technology for a better good } \\
\text { of the community. }\end{array}$ \\
\hline
\end{tabular}


In November 2019 the company ConsenSys collected the current status of usage of the blockchain technology by the governments - globally. We can summarize that the governments are careful and rather move slow with this technology, however the DLT format can be an important tool to support various public sector applications, including digital payments (even central bank digital currencies are under consideration in many countries), land and corporate registration, identity management and personal data storage, supply chains and movement of goods, health care... etc.

\section{APPLICATIONS OF BLOCKCHAIN}

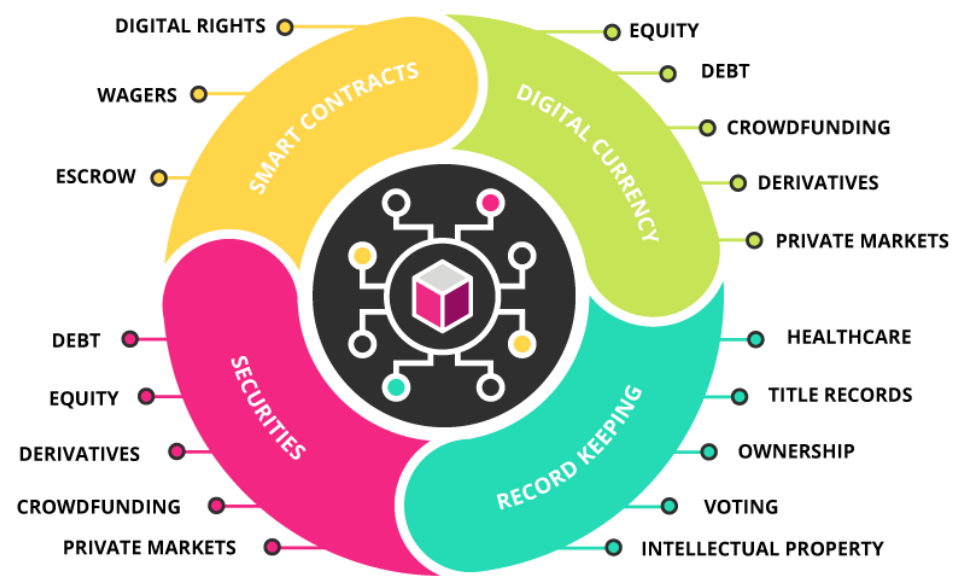

Figure 1 Applications of Blockechain

Source: GetSmarter ${ }^{2}$

\section{Obstacles of blockchain technology}

Despite of the several advantage of the technology, there are some factors hindering the overall usage of the DLT and blockchain. In the followings I've collected the most common points in the scientific literature that are detected as negative impacts.

(1) Cost and energy consumption: According to a study from 1 January 2016 to 30 June 2018 estimated that mining Bitcoin, Ethereum, Litecoin and Monero consumed an average of $17,7,7$ and $14 \mathrm{MJ}$ to generate one US\$, respectively. Comparatively, conventional mining of aluminium, copper, gold, platinum and rare earth oxides consumed 122, 4, 5, 7 and 9 MJ to generate one US\$, respectively, indicating that (with the exception of aluminium) cryptomining consumed more energy than mineral mining to produce an equivalent market value (Krause and Tolaymat 2018). According to a

${ }^{2}$ GetSmarter web publication, available: https://www.getsmarter.com/blog/market-trends/blockchainseffect-on-business/ (25th March 2020) 
Chinese study, the Monero mining in China may have consumed $30.34 \mathrm{GWh}$ and contribute a carbon emission of 19.12-19.42 thousand tons from April to December in 2018 (Li et al 2018). We saw in the previous section that blockchain technology can be a help achieving sustainability goals, but it should be also considered not to cause more harm than good. In this field the evolution of decision making processes and computing techniques can be a solution.

(2) Speed: Transaction speed - as heart of the blockchain technology - refers to the rate at which transfer of data happens from one account to the other. The speed of a blockchain, (which is calculated in seconds, but in case of larger chains, in minutes) depends upon various factors as block time, block size, transaction fees, and network traffic. It is an unsolved problem of blockchain technology how to make transaction speed higher without risking the stability of the chain. In the future several stress tests should be made to prove the results of different resolution methods.

(3) Long-term security: DLT and blockchain are based on trust within strangers. They put their trust in an algorithm (and service provider) that their data/value/action are securely administered and transferred. There are several kind of misuse cases, or intentional attacks on wallets, prive-keys, transaction privacy leakage. There is also a threat when blockchain is connected to IoT dives or is a part of a smart contract system, where the data input can also be manipulated.

(4) Political and economical risk of mining pools: To guarantee the reliability and consistency of the data and transactions, blockchain adopts the decentralized consensus mechanism, which is one of the innovation factors of blockchain. The two most popular blockchain systems (i.e., Bitcoin and Ethereum) use the Proof of Work (PoW) mechanism. PoW mechanism uses the solution of puzzles to prove the credibility of the data. The puzzle is usually a computationally hard but easily verifiable problem. When a node creates a block, it must resolve a PoW puzzle. After the PoW puzzle is resolved, it will be broadcasted to other nodes, so as to achieve the purpose of consensus ( $\mathrm{Li}$ et al 2020). A $51 \%$ attack refers to an attack on a blockchain by a group of miners controlling more than $50 \%$ of the network's mining hash rate or computing power. During the first years of blockchain technology, this scenario seemed to be impossible. In Januray 2014, after the mining pool ghash.io reached $42 \%$ of the total Bitcoin computing power, a number of miners voluntarily dropped out of the pool, and ghash.io issued a press statement to reassure the Bitcoin community that it would avoid reaching the $51 \%$ threshold. However, during 5-7 January 2019, a mining group has reached the 51\% majority of computing power on Ethereum blockchain, and stole at least 1,1 million USD-worth ETC through "double spending". It is easy realize that the $51 \%$ attack is real threat to this decentralized system.

\section{Conclusion}

Despite of the upper mentioned obstacles the blockchain technology is a great tool in the hands of the governments to securely store data, improve the financial services or other state-managed activities. When we have a detailed look at the Sustainable Development Goals, there is no one that cannot be supported by the DLT 
or blockchain technology. It is the responsibility of the regulator to analyze the risks and compare them with the possible positive effects of this technology.

\section{Literature:}

(1) Adams R., Kewell B., Parry G. (2018) Blockchain for Good? Digital Ledger Technology and Sustainable Development Goals. In: Leal Filho W., Marans R., Callewaert J. (eds) Handbook of Sustainability and Social Science Research. World Sustainability Series. Springer, Cham

(2) BIS Committee on Payments and Market Infrastructures (2017): Distributed ledger technology in payment clearing and settlement. ISBN 978-92-9259-031-4. Available: https://www.bis.org/cpmi/publ/d157.pdf

(3) CARI (2018): Consejo Argentino Para Las Relaciones Internationales: Financial Inclusion for Women: A Way Forward. Argentina, 2018. Available: https://www.g20-insights.org/wpcontent/uploads/2019/10/Financial-Inclusion-for-Women-Final.pdf

(4) Casalini, Lucio (2019): Blockchain and Smart Contracts - What Changes Lie Ahead for Banking and Financial Law? Diritto del Risparmio, 2019/9. pp. 1-8. Available: https://www.dirittodelrisparmio.it/2019/09/24/blockchain-and-smart-contracts/

(5) Chohan, Usman W. (2019): Blockchain and Environmental Sustainability: Case of IBM's Blockchain Water Management. Discussion Paper: Notes on the 21 2 st Century. Copy available: https://papers.ssrn.com/sol3/Delivery.cfm/SSRN ID3334154 code2508452.pde?abstractid=333 $\underline{4154 \& \text { mirid }=1}$

(6) ConsenSys (2019): Which Governments Are Using Blockchain Right Now? Available: https://consensys.net/blog/enterprise-blockchain/which-governments-are-using-blockchainrightnow $/$ ?utm campaign $=$ ConsenSys $\% 20$ Newsletter\&utm source $=$ hs email\&utm medium $=$ email\& utm content $=80467613 \&$ hsenc $=\mathrm{p} 2$ ANqtz--

zOUwxuYK6daqZLBVicSvsDfB415GmyrmqQ1XAqQ0DBWsYHR6cYWw7FnjsuktvdBE40ojH5MBFbBgDSRn1mh1AV0So0Oxmwv6hGdQVMHowXCOCQY\& hsmi $=80467613$

(7) Ekblaw, Ariel and Asaph Azaria and John D. Halamka and Andrew Lippman: A Case Study for Blockchain in Healthcare: "MedRec" prototype for electronic health records and medical research data. White paper.

(8) FAO (2019) E-agriculture in action: Blockchain for agricultura. Opportunities and Challenges. Issue paper. Available: http://www.fao.org/3/CA2906EN/ca2906en.pdf

(9) Herian, Robert (2018): Legal Recognitions of Blockchain Registries and Smart Contracts. Draft Report. Available: https://www.eublockchainforum.eu/reports

(10) Houben, Robby and Snyers, Alexander (2018): Cryptocurrencies and blockchain. Legal context and implications for financial crime, money laundering and tax evasion. European Parliament, Policy Department for Economic, Scientific and Quality of Life Policies. Available: https://www.europarl.europa.eu/cmsdata/150761/TAX3\%20Study $\% 20$ on $\% 20$ cryptocurrencies \%20and\%20blockchain.pdf

(11) IFS (2019): Blockchain: Opportunities for Private Enterprises on Emerging Markets. Second and Expanded Edition, January $2019 . \quad$ Available: http://documents.worldbank.org/curated/en/260121548673898731/pdf/134063-WP-1212782nd-edition-IFC-EMCompass-Blockchain-Report-PUBLIC.pdf

(12) Jiang, Shan at al: BlocHIE: a BLOCkchain-based platform for Healthcare Information Exchange. 2018 IEEE International Conference on Smart Computing. DOI 10.1109/SMARTCOMP.2018.00073.

(13) Kamath, Reshma (2018): Blockchain for Women Next Generation for Sustainable Development Goal 5. Journal of Poverty Alleviation \& International Development. Vol. 9 Issue 1, pp. 88-109.

(14) Kewell, Elizabeth and Adams, Richard and Parry, Glenn (2017) Blockchain for Good? Strategic Change, 26 (5). pp. 429-437.

(15) Krause, Max J. and Tolaymat, Thabet (2018): Quantification of energy and carbon costs for mining cryptocurrencies. Nature Sustainability, Vol. 1. pp. 711-718. https://doi.org/10.1038/s41893$\underline{018-0152-7}$ 
(16) Kshetri, Nir (2017) "Will blockchain emerge as a tool to break the poverty chain in the Global South?" Third World Quarterly, Available: http://www.tandfonline.com/doi/full/10.1080/01436597.2017.1298438

(17) Li, Jingming et al (2018): Energy consumption of cryptocurrency mining: A study of electricity consumption in mining cryptocurrencies. Energy. Vol. 168. pp. 160-168. https://doi.org/10.1016/i.energy.2018.11.046

(18) Li, Xiaoqui et al (2020): A survey on the security of blockchain systems. Future Generation Computer Systems. Vol. 107. pp. 841-853. https://doi.org/10.1016/j.future.2017.08.020

(19) Måren, Inge Elisabeth (2019): Food Systems for Sustainable Terrestrial Ecosystems (SDG 15). Food ethics Vol. 2, pp. 155-159. Available: https://doi.org/10.1007/s41055-018-00032-2

(20) Petrovic, Marina and George Harrap and Jamshed Kardikulov (2017): „From Russia to Tajikistan”: changing the way money moves. UNDP Europe an Central Asia, 25 July 2017. Available: https://www.eurasia.undp.org/content/rbec/en/home/blog/2017/7/25/-From-Russia-toTajikistan-changing-the-way-money-moves.html

(21) Pinna, Andrea and Simona Ibba (2017): A blockchain-based Decentralized System for a proper handling of temporary employment contracts. Computing Conference 2018, Copy available: arXiv:1711.09758v1

(22) Report (2014): UN: Report of the Intergovernmental Committee of Experts on Sustainable Development Financing, A/69/315. 15 August 2014.

(23) Scott, Brett (2016) : How can cryptocurrency and blockchain technology play a role in building social and solidarity finance?, UNRISD Working Paper, No. 2016-1, United Nations Research Institute for Social Development (UNRISD), Geneva

(24) Tripoli, Mischa and Schmidhuber, Josef (2018) Emerging Opportunities for the Application of Blockchain in the Agri-food Industry. FAO and ICTSD: Rome and Geneva. Licence: CC BY-NCSA 3.0 IGO.

(25) World Bank (2017) Distributed Ledger Technology (DLT) and blockchain. Available: http://documents.worldbank.org/curated/en/177911513714062215/pdf/122140-WP-PUBLICDistributed-Ledger-Technology-and-Blockchain-Fintech-Notes.pdf 